\title{
Troposzferikus maradék ellentmondások becslése az életbiztonságra veszélyes GNSS-alkalmazások esetén
}

\author{
Rózsa Szabolcs - Ambrus Bence - Juni Ildikó - Ober Pieter Bastiaan - Mile Máté
}

DOI: https://doi.org/10.30921/GK.70.2018.5.1

\section{Bevezetés}

A Globális Navigációs Múholdrendszerek (GNSS) magas integritásigényú alkalmazásai esetében a rendszer fó paramétere annak belsô megbízhatósága. Ezt a jellemzốt a védelmi szintek bevezetésével számszerúsítik, ami tulajdonképpen a pozíciómeghatározás hibáinak felülbecslése valamilyen nagyon kicsiny valószínúségi szinten. A felhasználó a védelmi szint előrejelzéséhez egy, a helymeghatározás hibájára vonatkozó modellt használ, amely azonban a múhold-vevô távolságmérése következtében fellépố hibák modelljeinek függvénye. Annak érdekében, hogy a védelmi szint kellôen konzervatív becslést adhasson, az összes fellépô hibára vonatkozó modellnek önmagában is konzervatív becslônek kell lennie. Cikkünkben a lehetséges hibaforrások egyikének - a troposzféra által okozott maradék hibáknak - a konzervatív modellezésével foglalkozunk.

A GNSS esetében a geocentrikus rendszerben végrehajtott helymeghatározást a múhold és a vevô közötti távolság meghatározására vezetjük vissza, amelyet a mérójelek terjedési idejének mérésével hajtunk végre. Az elektromágneses jelek a troposzférán való áthaladásuk során jelentős késleltetéseket szenvednek, melyek hatását rendszerint empirikus modellekkel csökkentik.

Magas integritásigényú felhasználások esetében, mint amilyen például a repülốgépes navigáció, az említett modellek validációjára van szükség annak érdekében, hogy a felhasználók biztonsággal dönthessenek a fedélzeti GNSS-vevôk által szolgáltatott koordinátamegoldás megbízhatóságáról.

A jelenleg de facto szabványként alkalmazott ajánlás (RTCA 2006) a troposzferikus maradék hibák esetében túlságosan konzervatívnak mondható, ami ugyan elônyös lehet a biztonság szemszögéból, azonban a rendszer elérhetôségét és a helymeghatározási szolgáltatás folytonosságát negatívan befolyásolja.

Az RTCA MOPS (Radio Technical Commission for Aeronautics Minimum Operational Performance Standards) dokumentumban ismertetett troposzféramodell egy globálisan konstans értékben $(0,12 \mathrm{~m})$ maximálja a zenit irányú maradék hiba szórását. Habár a szabályozás nem részletezi e konstans megállapításának módját, Collins és Langley (1998) eredményei is alátámasztják a 0,12 méteres értéket.

Van Leeuwen et al. (2004) is tanulmányozták a fent említett modellt Hollandia területén, ami alapján arra a megállapításra jutottak, hogy az túlságosan konzervatív. Ez alapján tehát úgy tûnik, hogy valós igény mutatkozhat egy új, kevésbé konzervatív, azonban a biztonságot nem kompromittáló modell kifejlesztésére.

Mivel a közeljövôben várhatóan a többfrekvenciás GNSS-vevôk köré fog csoportosulni az alkalmazások jelentôs része, az ionoszferikus hatások egyre kevésbé lesznek meghatározó hibaforrások. A troposzféra által okozott késleltetések azonban nem küszöbölhetôk ki a különböző vivőfrekvenciák alkalmazásával, ezért továbbra is szükség lesz minél pontosabb, nagy megbízhatóságú empirikus modellekre.

Az alábbi cikkben egy új, fejlett eljárást mutatunk be a troposzferikus maradék ellentmondások becslésére, melynek alapja az általános extrémérték-elmélet. Annak érdekében, hogy a modell mind a biztonság, mind az elérhetôség szempontjából optimális legyen, figyelembe veszi a maradék ellentmondások szezonális és éghajlati függését is.

\section{A troposzferikus maradék hibák szerepe a GNSS-rendszerek integritásában}

A GNSS rendszerek esetében a rendszer integritása a korábban említett védelmi szintek segítségével számszerûsíthetô. A védelmi szintek a helymeghatározás hibájának felülbecsléseként képzelhetôk el, melyek meghaladása csak rendkívül kicsiny valószínúségi szinten megengedett (ez a szint jellemzốn $10^{-7}-10^{-9}$ között van). Amikor a kiszámított védelmi szint meghaladja az adott alkalmazáshoz szükséges elfogadható mértéket, a felhasználó már nem bízhat a meghatározott pozícióban és alternatív helymeghatározási módokhoz kell fordulnia. A felhasználó a védelmi szintet különbözó modellekkel számíthatja, melyek a helymeghatározáshoz használt távméréseket terhelő hibák felülbecslésével jönnek létre.

Az RTCA (2006) ajánlása maradék hibaértékeket határoz meg a pálya és az órahibákra, a vevôantennát terheló zajra, valamint az ionoszferikus és troposzferikus késleltetésekre. Ezen ellentmondások mindegyike zérus középértékú normális eloszlás szórásával írható le. A múhold irányú hiba szórása:

$$
\sigma_{i}^{2}=\sigma_{i, f l t}^{2}+\sigma_{i, \text { UIRE }}^{2}+\sigma_{i, \text { air }}^{2}+\sigma_{i, \text { tropo }}^{2}
$$

ahol:

- $\sigma_{i}$ az i-edik múholdhoz tartozó pszeudotávolság mérés szórása [m],

- $\sigma_{i, f t}^{2}$ az idóben gyorsan valamint hoszszabb távon változó korrekciók maradék hibájának a varianciája $\left[\mathrm{m}^{2}\right]$,

- $\sigma_{i, \text { UIRE }}^{2}$ a ferde irányú ionoszferikus késleltetés maradék hibájának varianciája $\left[\mathrm{m}^{2}\right]$,

- $\sigma_{i, a i r}^{2}$ a repülógépen lévố vevố hibáihoz tartozó variancia $\left[\mathrm{m}^{2}\right]$,

- $\sigma_{i, \text { tropo }}^{2}$ a troposzferikus késleltetés maradék hibájának variancája $\left[\mathrm{m}^{2}\right]$.

A maradék troposzferikus ellentmondás az alábbiak szerint számítható az i-edik múhold irányában:

$$
\begin{aligned}
& \sigma_{i, \text { tropo }}^{2}=\sigma_{T V E} \cdot m\left(\theta_{\mathrm{i}}\right), \\
& m\left(\theta_{i}\right)=\frac{1.001}{\sqrt{0.002001+\sin ^{2} \Theta_{i}}}
\end{aligned}
$$

ahol a $\sigma_{T V E}$ a zenitirányban meghatározott troposzferikus maradék hiba (értéke 0,12 méter) $\theta_{i}$ pedig a múhold 
magassági szöge. Megfigyelhetô, hogy a zenit irányú hiba egy globálisan konstans érték, mely elhanyagolja a troposzferikus késleltetések meghatározási pontosságának a földrajzi szélességtől és az évszakoktól való függését. Ezáltal azonban a világ számos területén túlságosan konzervatív becslést szolgáltat.

A felsorolt tényezók együttes figyelembevételével megállapítható a teljes maradék hiba varianciája, ami alapján kiszámítható a horizontális valamint a vertikális védelmi szint (horizontal/ vertical protection level - HPL/VPL):

$$
\begin{aligned}
& H P L=K_{H} \cdot d_{\text {major }}, \\
& V P L=K_{V} \cdot d_{U},
\end{aligned}
$$

ahol $K_{H}$ és $K_{V}$ a különbözố repülógéplandolási eljárásoktól függő konstansok, $d_{\text {major }}[\mathrm{m}]$ pedig a hibaellipszis fônagytengelyéhez tartozó bizonytalanságot jellemzi:

$$
d_{\text {major }}=\sqrt{\left(\left(\frac{d_{\text {east }}^{2}+d_{\text {north }}^{2}}{2}\right)+\sqrt{\left(\frac{d_{\text {east }}^{2}-d_{\text {north }}^{2}}{2}\right)^{2}+d_{E N}^{2}}\right)}
$$

A képletben szereplő tagok jelentése a következő:

- $d_{\text {east }}^{2}$ a keleti koordinátatengely mentén értelmezett hibaeloszlást felülbecsló modell varianciája $\left[\mathrm{m}^{2}\right]$,

- $d_{\text {north }}^{2}$ az északi koordinátatengely mentén értelmezett hibaeloszlást felülbecslố modell varianciája $\left[\mathrm{m}^{2}\right]$,

- $d_{E N}^{2}$ a modelleloszlás kovarianciája a keleti és északi koordinátatengelyek mentén $[\mathrm{m}]$,

- $d_{U}^{2}$ a függőleges tengely mentén értelmezett hibaeloszlást felülbecslő modell varianciája $\left[\mathrm{m}^{2}\right]$.

Az összes modellvariancia számítása a helymeghatározási hiba megfelelô irányban vett parciális deriváltjaival történik.

A HPL és a VPL értékek felhasználásával a rendszer ellenốrizheti, hogy az aktuálisan elérhető pontosság megfelel-e a navigációs követelményeknek.

\section{A modellfejlesztés módszertana}

A navigációs kiegészítô rendszerekre vonatkozó általános integritásbeli követelményeket az ICAO (2006) foglalja össze. Ez alapján a GNSShelymeghatározó rendszer a megközelítési eljárások esetében $2 \times 10^{-7}$-es szignifikancia szinten vizsgálandó. Amennyiben egy idôben egyetlen megközelítést feltételezünk és egy megközelítés hosszát 150 másodpercre becsüljük, akkor a rendszer integritásvesztésének visszatérési ideje hozzávetôlegesen 25 év.

Mivel nem állnak rendelkezésre a hibákra vonatkozó adatok a rendszer teljesítményének vizsgálatához, így egy valószínúségi alapokon nyugvó megközelítésre van szükség. Elsố megfontolásra a maradék hibák becslése történhetne a múhold-vevô irányban a légköri paraméterek ismeretében sugárkövetéssel meghatározott „tényleges" késleltetési értékek és az RTCAtroposzféra modell által szolgáltatott késleltetési értékek különbségképzésével, majd az így kapott eredményekre egy normális eloszlás illesztésével. Ezután a maradék ellentmondások bármilyen szignifikanciaszinten becsülhetôk lennének. A probléma abban rejlik, hogy a troposzferikus késleltetés maradék hibái, az eloszlás szárnyai általában nem követik a normális eloszlás lefutását. Az 1. ábrán egy tipikus, a normális eloszláshoz tartozó valószínúségi ábra látható a hidrosztatikus troposzferikus késleltetések maradék hibáira vonatkozóan. Az ábrából látszik, hogy az eloszlás szárnyain a hibák nem követik a normális eloszlást.

Annak érdekében, hogy az eloszlás szárnyainak jellegét is figyelembe vegyük, a maradék hibák vizsgálatához az extrémérték-elemzést hívtuk segítségül. Ez a matematikai eljárás széles körben használt például árvízi vízszintek becslésénél, de újabban a GNSS és a hozzá tartozó kiegészítô rendszerek vizsgálatára is alkalmazzák (Ober 2014).

A Fischer-Tippett-Gnedenko tétel kimondja, hogy független és azonos eloszlású valószínúségi változók maximuma megfelelố normalizálás után az alábbi három lehetséges eloszlás felé konvergál, nevezetesen a Gumbel-, a Fréchet- vagy a Weibull-eloszlás felé.

A három eloszlás jellemzôi a következők:

$$
H(x)=\left\{\begin{array}{cc}
0 & \text { ha } x \leq 0 \\
\exp \left\{-x^{-\alpha}\right\} & \text { ha } x>0
\end{array}\right.
$$

a Fréchet-eloszlás esetében,

$$
H(x)=\left\{\begin{array}{cc}
\exp \left\{-(-x)^{-\alpha}\right\} & \text { ha } x<0 \\
1 & \text { ha } x \geq 0
\end{array}\right.
$$

a Weibull eloszlás esetében és

$$
H(x)=\exp \{-\exp \{-x\}\} x \in R
$$

a Gumbel-eloszlás esetében

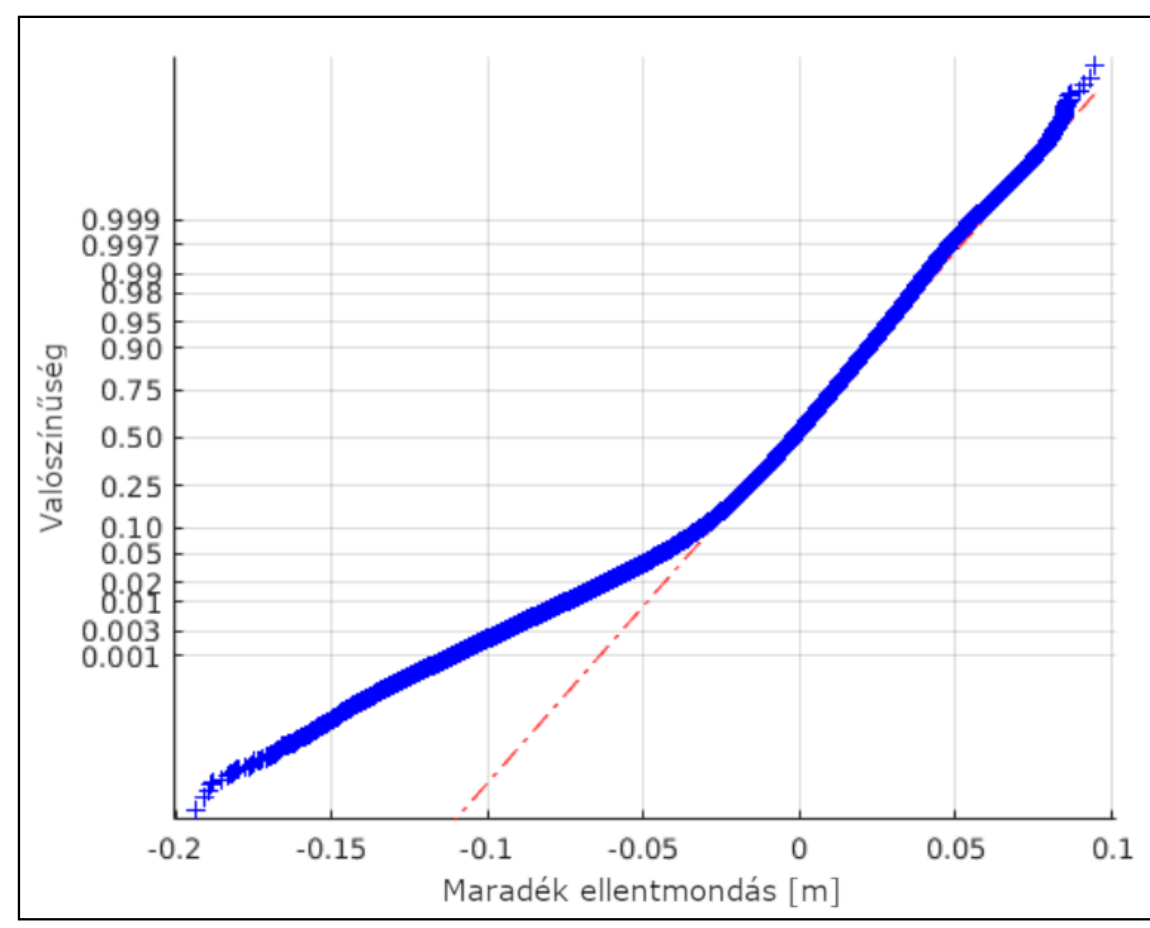

1. ábra. A hidrosztatikus troposzferikus késleltetések maradék hibáinak valószinúségi ábrája az északi szélesség $40^{\circ}$ és $50^{\circ}$ közötti sávra vonatkozóan 2000 és 2016 között. A maradék hibák az RTCA-troposzféramodell által becsült és az ECMWF ERA-Interim numerikus idôjárásmodellböl sugárkövetéssel levezetett referenciaadatok különbségei. 
A Jenkinson (1995) által bevezetett általánosított extrémérték-elmélet (Generalized Extreme Value theory - GEV) egyesíti a fenti három eloszlást egy általános extrémérték-eloszlássá. Az eloszlás képlete a következô:

$$
H(x)=\left\{\begin{array}{lr}
\exp \left\{-\left[1-\frac{k(x-\xi)}{\alpha}\right]^{\frac{1}{k}}\right\} & \text { ha } k \neq 0 \\
\exp \left\{-\exp \left\{\frac{-x-\xi}{\alpha}\right\}\right\} & \text { ha } k=0
\end{array}\right.
$$

ahol az $x$ változót a $\xi+\alpha / k$ határolja felülről, ha $k>0$, illetve alulról, ha $k<0$. $\xi$ és $\alpha$ az ún. helyzeti és skálaparaméterek, $k$ pedig az ún. alaktényezô. Az alaktényezô befolyásolja, hogy végsố soron melyik eloszlással van dolgunk:

- $k>0$ esetében a Fréchet-eloszlással, - $k=0$ esetében a Gumbel-eloszlással,

- $k<0$ esetében pedig a Weibulleloszlással.

\section{A maradék troposzferikus késleltetésekre vonatkozó modell levezetése}

Annak érdekében, hogy egy troposzféramodell megfelelőségét vizsgálhassuk, a maradék hibák kiszámítására van szükség. Az RTCA-modell által szolgáltatott késleltetésbecsléseket össze kell hasonlítani a troposzferikus késleltetések „valódi” értékével. Mivel ezen „valódi” értékek nem ismertek, a zenit irányú troposzferikus késleltetésekre vonatkozó referenciaként numerikus idójárási modellek adatsoraira épülő és sugárkövetéssel meghatározott adathalmazt használtunk Az extrémérték-analízist a két adatsor különbségeként kapott maradék hibákra alkalmaztuk.

\section{Meteorológiai adatok}

A maradék hibák modellezése számos különbözô meteorológiai adathalmaz felhasználásával történhet. Collins és Langley (1998) az UNB3 troposzféramodell maradék hibáinak meghatározására például az ÉszakAmerikában felbocsátott rádiószondák adatait használták és kimutatták, hogy a maximális maradék hiba zenit irányban $60 \mathrm{~cm}$ körül mozog. Ugyanakkor, mivel a rádiószondás adatok nem fedik le a teljes Föld felszínét, megfelelô sû́rûséggel, ezért esetünkben más adatsor felhasználása volt szükséges.

A bemenô meteorológiai adatok kiválasztásánál az alábbi szempontokat vettük figyelembe:

- megfelelôen hosszú idôt magába foglaló adatsorra van szükség, ugyanis az extrémérték-elmélet az eloszlás szélein extrapolációt alkalmaz;

- a meteorológiai adatoknak stacionáriusnak kell lenniük, valamint konzisztens feldolgozási eljárással kell óket levezetni a vizsgált idôszakra vonatkozóan;

- az adathalmaznak megfelelôen kell jellemeznie a meteorológiai paraméterek szezonális és éghajlati változását.

A feltételek teljesítése érdekében a Középtávú Idôjárás Elôrejelzések Európai Központja (European Center for Medium Range Weather Forecasts ECMWF) által szolgáltatott ERA-Interim (Dee et al. 2011) $1^{\circ} \times 1^{\circ}$ felbontású adatsoraira támaszkodtunk. Habár az adatok 1979-ig visszamenôen rendelkezésre állnak, vizsgálatunk a 2000 és 2016 közötti 17 éves periódusra terjedt ki. $\mathrm{Az}$ adatsor napi négy értéket tartalmazott, 00, 06, 12 és 18 UTC idópontokra vonatkozóan. A kiválasztott intervallum egyrészt lehetôséget adott, hogy minimalizáljuk a klímaváltozás által okozott hatásokat, másrészt a 25 éves visszatérési idôt tekintve, az extrapoláció szempontjából is kielégítônek mondható.

A múhold irányú troposzferikus késleltetés becslése a numerikus időjárásmodell adatsorának felhasználásával, a sugárkövetés módszerével történt. Mivel az ECMWF-modell legfelsőbb szintje felett található semleges atmoszféra még jelentôsen befolyásolja a jelterjedést (Rózsa 2014), ezért az adatsort kiterjesztettük 86 kilométer magasságig a Nemzetközi Szabványos Atmoszféra (International Standard Atmosphere - ISA) adataival. A magasságokat és a hozzájuk tartozó meteorológiai paramétereket Rocken et al. (2001) által ismertetett módszerrel felülmintavételeztük.

\section{A maradék hibák modellezése}

A maradék hibák modellezéséhez először előállítottuk a troposzferikus késleltetések referenciaértékét az ECMWF meteorológiai adatokra épülő sugárkövetéssel (Boehm-Schuh 2003). A sugárkövetést minden rácspontban zenit irányban, valamint $3^{\circ}$-os, $5^{\circ}$-os, $10^{\circ}$-os és $45^{\circ}$-os magassági szögekre hajtottuk végre mind a hidrosztatikus, mind a nedves késleltetés esetében. Ezek közül további felhasználásra jelen munkánkban csak a zenit irányú eredmények kerültek.

Ezután a maradék hibákat megkaphattuk, ha az empirikus modellek által becsült késleltetés értékeket levontuk a referenciaadatokból. Az éghajlati és szezonális hatások a maradék hibák idôsorában is felfedezhetôk. A 2. ábra a hidrosztatikus késleltetés maradék hibáit mutatja a $31^{\circ}$ és $40^{\circ}$ északi szélességek között elhelyezkedố sávban. Az ábráról leolvasó, hogy a maradék hibák terjedelmének jelentôs szezonális fluktuációja van. Annak érdekében, hogy az extrémérték-elemzés elvégezhető legyen, elôször az adatsor normalizálására van szükség. Ehhez valamilyen, az egyes napokhoz tartozó maradék hibák szórásának szezonális változását jól leíró függvény alkalmazható. Az így megkapott normalizált ellentmondásokra már végrehajtható az extrémértékelemzés. Végül, a maximális maradék troposzferikus késleltetés a korábban használt függvény segítségével az év bármely napjára kiszámítható. A 2. ábrából ugyanakkor az is látszik, hogy a maradék hibák a zérushoz képest jelentôs eltolódással (ún. bias-szel) rendelkeznek, melynek szintén van egy szezonális váltakozása. Elméleti szempontból szükség lenne a bias érték figyelembe vételére, azonban a modellalkotás során a normalizáláskor mi zérus átlagot feltételeztünk. Ezen egyszerúsítés oka, hogy amennyiben a bias elôzetesen levonásra kerül, késôbb, a védelmi szint számításakor ugyanúgy szükség van a visszaállítására. Mivel az RTCA MOPS javaslata alapján a védelmi szinteket zérus középérték feltételezésével és egyszerú hibaterjedéssel történô levezetéssel számolják, az összhang megtartása érdekében mi is ezt a feltételezést választottuk a normalizációs lépés során.

A maradék hibák normalizálása érdekében elôször egy periodikus függvényt illesztettünk az ellentmondások szórásának napi értékeire, 


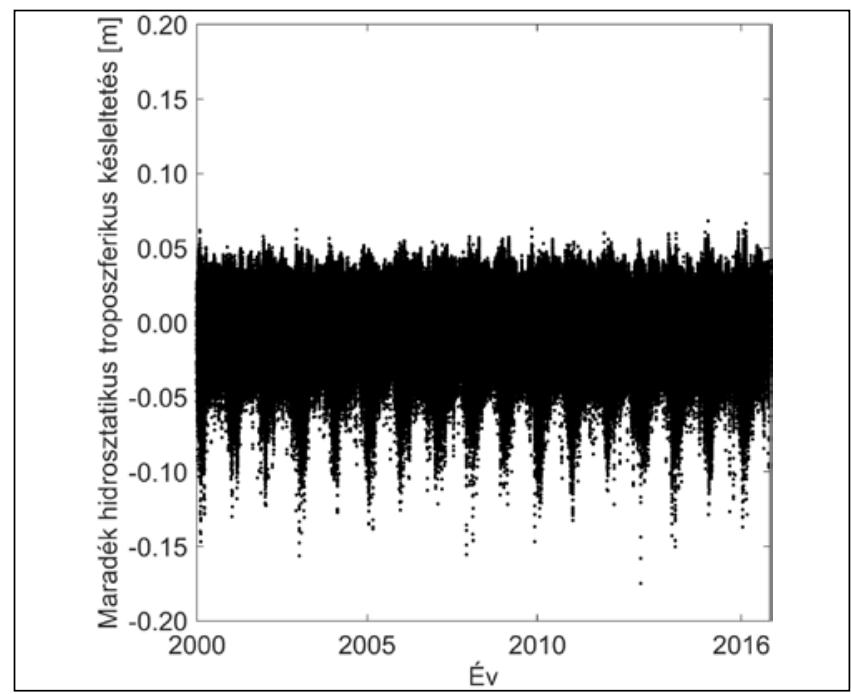

2. ábra. A hidrosztatikus maradék ellentmondások idôsora a $40^{\circ}$ és $30^{\circ}$ északi szélességek közötti sávban.
- $A_{2}$ a szezonális változás féléves összetevőjének amplitúdója.

A napi maradék ellentmondásokhoz tartozó szórás értékek és az illesztett modell függvény a 3. ábrán látható.

Ezután a maradék hibák normalizálása történt meg az alábbi módon:

$\delta_{n}=\frac{\delta}{\sigma(D O Y)}$

A következô lépésben a normalizált melyben figyelembe vettük a szezonális változás éves, valamint féléves összetevôit (lásd 3. ábra).

A napi szórásértékekre vonatkozó periodikus függvény:

$\sigma(D O Y)=A_{0}+A_{1} \cos \left(\frac{D O Y-D O Y_{0}}{365.25} 2 \pi\right)+$

$$
+A_{2} \cos \left(\frac{D O Y-D O Y_{0}}{365.25} 4 \pi\right)
$$

ahol az ismeretlen paraméterek a következôk:

- $A_{0}$ a maradék hibák napi szórásértkeinek átlaga a teljes idôsorra vonatkozóan,

- DOY a napi maradék hibák éves extrémértékéhez tartozó nap (a fázis),

- $A_{1}$ a szezonális változás éves összetevőjének amplitúdója,

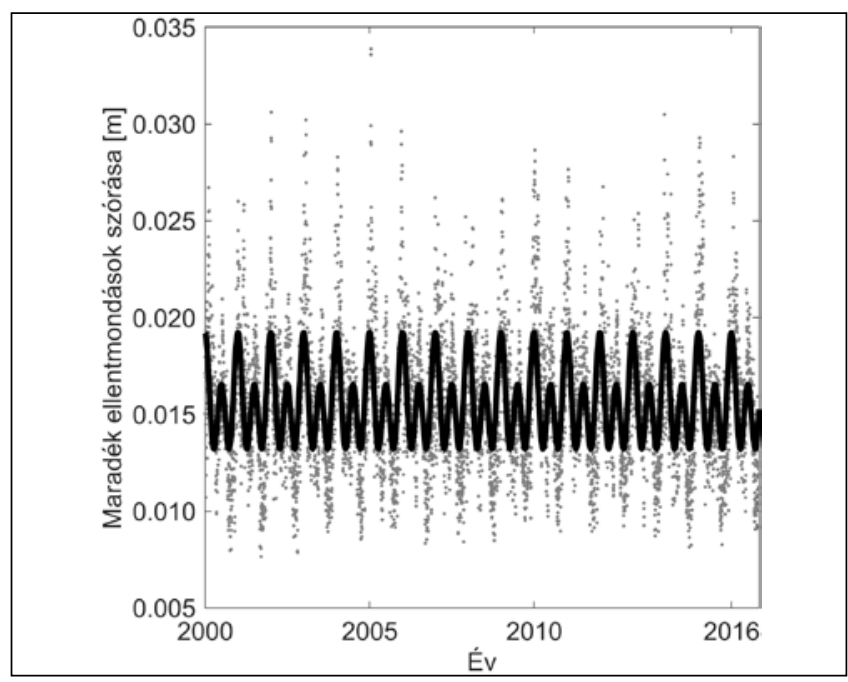

3. ábra. A napi maradék hibák szórásának szezonális változása a $31^{\circ}$ és $40^{\circ}$ északi szélességek között elhelyezkedô sávban,valamint az éves és féléves periodicitást figyelembe vevố illesztett modell. maradék ellentmondások extrémérték-elemzését hajtottuk végre. Ennek során összesen 17 éves extrémérték (maximum és minimum) került meghatározásra. A korábban ismertetett GEV eloszlást ráillesztettük az extrémértékekre, majd ebból extrapolálással meghatároztuk a 25 éves visszatérési időhöz tartozó pozitív és negatív extrémértékeket. A két érték közül a nagyobb abszolút értékút választottuk, mint a normalizált maradék ellentmondások maximális várható értékét $\left(\Delta_{\mathrm{n}, \max }\right)$.

Mivel az RTCA MOPS ajánlása szerint a védelmi szinteket normális eloszlású valószínúségi változók szórásából kiindulva számítják, ezért arra volt szükség, hogy a becsült maximális hibát egy szórás jellegú mennyiséggé alakítsuk át:

$$
\sigma_{n, \max }=\frac{\Delta_{n, \max }}{K}
$$

ahol $K=5.33$, figyelembe véve a standard normális eloszlást a $1-10^{-7}$ valószínúségi szinten. hogy a normalizálás zérus középérték feltételezésével történt. Amennyiben nem ez az eset áll fent, úgy a modell elvesztheti felülbecslő jellegét. Ezt elkerülendô, a meghatározott maximális szórás értéket megnöveltük egy konstans értékkel, ami az eredeti maradék hibák legnagyobb napi középértékével egyezik meg. Így tehát a maximális szórás a következôképpen alakul:

$$
\sigma_{\max }(D O Y)=\frac{\Delta_{0}}{K}+\sigma(D O Y)
$$

ahol $\Delta_{0}$ egy eltolási paraméter. A maximális bias értékek becslése szintén extrémérték-elemzéssel történt, ezúttal a napi maradék ellentmondások középértékeire illesztve az extrémérték-eloszlást (lásd 4. ábra). A modell összhangjának fenntartása érdekében a napi bias értékeket szintén 25 éves visszatérési idô figyelembevételével határoztuk meg.

Végül, a maximális maradék troposzferikus késleltetés értéke az év bármely napjára (DOY) az alábbi képlettel számítható:
Figyelembe kell vennünk azonban, 


\section{A levezetett maradék troposzferikus \\ késleltetési modellek}

Habár a maradék hibák modellezése rácspontonként is elvégezhető, célszerú a lehető legegyszerúbb modell létrehozására törekedni, ugyanis végsố soron ezeket a modelleket a GNSSvevốk firmware-jében kell tárolnunk. A RTCA MOPS ajánlásának egyik elônye pontosan az egyszerúségében rejlik, ugyanis mindössze egyetlen konstans érték eltárolására van szükség ahhoz, hogy a zenit irányú maximális maradék troposzferikus késleltetést meghatározhassuk a Föld bármely pontján.

Annak érdekében, hogy a számítás egyszerúségének megốrzése mellett egy kevésbé konzervatív, de a biztonságot nem kompromittáló modellt szolgáltassunk a maradék hibák becsléséhez, összesen három különbözô modellszintet alakítottunk ki (Advanced Residual Tropospheric Error model - ARTE):

- ARTE Szezonális Sávos Modell (ARTE Band Seasonal Model - ARTE-BSM): ezen a szinten a modell az összes olyan paramétert szolgáltatja, mellyel figyelembe vehetô a szezonális változás az adott $10^{\circ}$-os szélességi sávon belül, így tehát nem csak az éghajlati, hanem a maradék hibák szezonális változása is modellezett.

- ARTE Konstans Sávos Modell (ARTE Band Constant Model - ARTE-BCM): ez a modellszint egyetlen értéket határoz meg a maximális maradék hiba mértékére, minden $10^{\circ}$-os szélességi sávban. A szezonális változást tehát elhanyagolja a modell, viszont az éghajlati változást figyelembe veszi.

- ARTE Globális Konstans Modell (ARTE Global Constant Model ARTE-GCM): ez a modell egyetlen globális konstans értéket határoz meg a Föld teljes területére. Habár a legegyszerúbb, a maradék hibáknak mind a szezonális, mind az éghajlati függését elhanyagolja.

\section{ARTE Szezonális Sávos Modell}

Az ARTE-BSM modell a (15)-ben szereplő összes paramétert $\left(\Delta_{0}, A_{0}, A_{1}, A_{2}\right.$, $\left.D O Y_{0}, \sigma_{\mathrm{n}, \max }\right)$ szolgáltatja az egyes $10^{\circ}$-os szélességi sávokra. A különbözó sávokra vonatkozó hidrosztatikus és nedves

késleltetésekhez tartozó együtthatókat az 1., illetve a 2. táblázat tartalmazza.

Az ARTE-BSM modell paraméterei az egyes sávokra

a hidrosztatikus maradék késleltetés esetében

1. táblázat

\begin{tabular}{|c|c|c|c|c|c|c|c|c|}
\hline Sáv & $\begin{array}{c}\Delta_{0} \\
{[\mathrm{~mm}]}\end{array}$ & $\begin{array}{c}A_{0} \\
{[\mathrm{~mm}]}\end{array}$ & $\begin{array}{c}A_{1} \\
{[\mathrm{~mm}]}\end{array}$ & $\begin{array}{c}A_{2} \\
{[\mathrm{~mm}]}\end{array}$ & $\begin{array}{c}A_{3} \\
{[\mathrm{~mm}]}\end{array}$ & $\begin{array}{c}A_{4} \\
{[\mathrm{~mm}]}\end{array}$ & $\begin{array}{l}\mathrm{DOY}_{0} \\
\text { [nap] }\end{array}$ & $\sigma_{n, \max }$ \\
\hline \multicolumn{9}{|c|}{ Északi félteke } \\
\hline $90-81$ & 87,8 & 14,1 & 2,8 & 0,4 & $-0,2$ & 0,2 & 2 & 2,0 \\
\hline $80-71$ & 51,0 & 21,6 & 6,0 & 1,6 & $-0,1$ & 0,4 & 0 & 1,3 \\
\hline $70-61$ & 43,2 & 22,9 & 8,4 & 1,5 & 0,1 & 0,0 & 0 & 1,3 \\
\hline $60-51$ & 29,7 & 24,3 & 10,0 & 1,8 & 0,5 & 0,1 & 1 & 1,5 \\
\hline $50-41$ & 26,6 & 20,9 & 7,0 & 2,5 & 2,0 & 0,7 & 0 & 1,7 \\
\hline $40-31$ & 20,7 & 15,6 & 1,3 & 1,8 & 2,3 & 1,1 & 0 & 2,1 \\
\hline $30-21$ & 15,2 & 11,6 & $-3,6$ & 0,4 & 1,5 & 1,0 & 3 & 2,7 \\
\hline $20-11$ & 16,0 & 7,1 & $-2,1$ & 0,1 & 0,6 & 0,4 & 8 & 3,9 \\
\hline $10-0$ & 17,5 & 4,6 & $-0,2$ & $-0,1$ & 0,4 & 0,2 & 1 & 3,3 \\
\hline \multicolumn{9}{|c|}{ Déli félteke } \\
\hline $1-10$ & 17,3 & 5,0 & $-0,2$ & $-0,5$ & 0,4 & 0,2 & 3 & 2,6 \\
\hline $11-20$ & 15,3 & 6,7 & 0,8 & $-0,3$ & 0,5 & 0,4 & 2 & 3,6 \\
\hline $21-30$ & 10,6 & 10,2 & 0,3 & $-0,9$ & 0,7 & 0,5 & 2 & 2,3 \\
\hline $31-40$ & 21,1 & 16,4 & $-2,8$ & $-1,6$ & 0,5 & 0,1 & 0 & 2,0 \\
\hline $41-50$ & 41,8 & 25,1 & $-3,4$ & $-1,5$ & 0,0 & 0,0 & 0 & 1,4 \\
\hline $51-60$ & 73,9 & 31,3 & $-3,4$ & $-1,3$ & $-0,9$ & 0,4 & 2 & 1,3 \\
\hline $61-70$ & 101,1 & 26,6 & $-5,2$ & $-2,1$ & $-1,0$ & 0,5 & 0 & 1,8 \\
\hline $71-80$ & 97,1 & 23,0 & $-8,6$ & $-5,4$ & $-0,3$ & $-0,4$ & 1 & 2,8 \\
\hline $81-90$ & 92,4 & 13,2 & $-5,4$ & $-3,3$ & $-0,3$ & 0,0 & 1 & 4,0 \\
\hline
\end{tabular}

Az ARTE-BSM modell paraméterei az egyes sávokra

a nedves maradék késleltetés esetében

2. táblázat

\begin{tabular}{|c|c|c|c|c|c|c|c|c|}
\hline Sáv & $\begin{array}{c}\Delta_{0} \\
{[\mathrm{~mm}]}\end{array}$ & $\begin{array}{c}A_{0} \\
{[\mathbf{m m}]}\end{array}$ & $\begin{array}{c}A_{1} \\
{[\mathbf{m m}]}\end{array}$ & $\begin{array}{c}A_{2} \\
{[\mathrm{~mm}]}\end{array}$ & $\begin{array}{c}A_{3} \\
{[\mathrm{~mm}]}\end{array}$ & $\begin{array}{c}A_{4} \\
{[\mathrm{~mm}]}\end{array}$ & $\begin{array}{l}D_{0 Y} \\
\text { [nap] }\end{array}$ & $\sigma_{n, \max }$ \\
\hline \multicolumn{9}{|c|}{ Északi félteke } \\
\hline $90-81$ & 70,4 & 8,5 & $-3,8$ & $-2,7$ & 0,8 & 1,5 & 6 & 2,9 \\
\hline $80-71$ & 54,6 & 15,5 & $-5,6$ & $-3,5$ & 1,1 & 1,5 & 1 & 1,9 \\
\hline $70-61$ & 55,7 & 22,3 & $-6,7$ & $-3,9$ & 1,8 & 1,5 & 2 & 1,6 \\
\hline $60-51$ & 59,8 & 29,0 & $-6,0$ & $-4,5$ & 1,8 & 1,4 & 3 & 1,2 \\
\hline $50-41$ & 60,2 & 37,3 & $-6,1$ & $-5,8$ & 0,8 & 1,2 & 1 & 1,1 \\
\hline $40-31$ & 72,5 & 47,7 & $-10,7$ & $-6,7$ & 2,1 & 1,1 & 2 & 1,0 \\
\hline $30-21$ & 89,9 & 59,7 & $-13,6$ & $-5,1$ & 2,8 & 0,0 & 0 & 0,8 \\
\hline $20-11$ & 117,6 & 57,0 & $-1,2$ & $-1,4$ & 1,3 & $-5,4$ & 0 & 1,0 \\
\hline $10-0$ & 58,6 & 46,8 & 6,7 & 1,6 & 1,1 & 2,9 & 1 & 0,9 \\
\hline \multicolumn{9}{|c|}{ Déli félteke } \\
\hline $1-10$ & 74,6 & 55,3 & 2,4 & $-6,5$ & 3,4 & $-2,0$ & 2 & 0,7 \\
\hline $11-20$ & 120,1 & 61,0 & 9,0 & 2,2 & 2,0 & $-1,3$ & 1 & 0,9 \\
\hline $21-30$ & 100,8 & 53,6 & 9,5 & 3,9 & 1,3 & 1,0 & 0 & 0,8 \\
\hline $31-40$ & 111,3 & 42,6 & 7,0 & 5,1 & 0,1 & 1,1 & 2 & 0,9 \\
\hline $41-50$ & 97,1 & 34,1 & 4,6 & 4,5 & $-0,2$ & 0,7 & 0 & 1,1 \\
\hline $51-60$ & 94,6 & 25,1 & 2,3 & 3,0 & $-0,5$ & 0,5 & 1 & 1,1 \\
\hline $61-70$ & 86,4 & 17,2 & 1,0 & 1,5 & $-0,4$ & 0,2 & 2 & 1,3 \\
\hline $71-80$ & 60,8 & 13,9 & 6,6 & 4,4 & $-0,8$ & $-0,2$ & 1 & 2,5 \\
\hline $81-90$ & 48,2 & 9,2 & 5,9 & 3,8 & $-0,7$ & $-0,5$ & 3 & 5,1 \\
\hline
\end{tabular}


Ennek a modellnek a legnagyobb elónye, hogy mind a szezonális, mind az éghajlati változásokat figyelembe veszi a maximális maradék késleltetés becslésekor (lásd 5. ábra). A modellel továbbá egymástól függetlenül megbecsülhetô a maximális maradék késleltetési hiba zenit irányú hidrosztatikus és a nedves összetevő́je is, ezáltal akár eltérố leképzési függvényt is felhasználhatunk az egyes komponensekre.

\section{ARTE Konstans sávos modell}

Habár az ARTE-BSM modell figyelembe veszi a szezonális és az éghajlati változást, bizonyos esetekben a számítási komplexitás problémát okozhat. Ennek elkerülésére egy egyszerúbb modell is megalkotásra került.
Az ARTE-BCM a szezonális sávos modellból került levezetésre, az egyes sávokra vonatkozó, (15) szerint kiszámított maradék késleltetések éves maximumának meghatározásával. Az i-edik sávra vonatkozóan:

$$
\sigma_{\max , i}=\max \left(\sigma_{\max }(D O Y, i)\right)
$$

\begin{tabular}{|c|c|c|c|c|}
\hline \multicolumn{5}{|r|}{ 3. táblázat. } \\
\hline \multirow[b]{2}{*}{ Sáv } & \multicolumn{2}{|c|}{ Északi félteke } & \multicolumn{2}{|c|}{ Déli félteke } \\
\hline & $\begin{array}{c}\text { Hidrosztatikus } \\
\sigma_{\max }[\mathbf{m}]\end{array}$ & $\begin{array}{c}\text { Nedves } \\
\sigma_{\max }[\mathbf{m}]\end{array}$ & $\begin{array}{c}\text { Hidrosztatikus } \\
\sigma_{\max }[\mathbf{m}]\end{array}$ & $\begin{array}{c}\text { Nedves } \\
\sigma_{\max }[\mathbf{m}]\end{array}$ \\
\hline $90-81$ & 0,05 & 0,06 & 0,08 & 0,07 \\
\hline $80-71$ & 0,05 & 0,06 & 0,11 & 0,07 \\
\hline $70-61$ & 0,05 & 0,06 & 0,08 & 0,04 \\
\hline $60-51$ & 0,06 & 0,06 & 0,06 & 0,05 \\
\hline $50-41$ & 0,06 & 0,06 & 0,05 & 0,06 \\
\hline $40-31$ & 0,05 & 0,08 & 0,04 & 0,07 \\
\hline $30-21$ & 0,05 & 0,08 & 0,04 & 0,08 \\
\hline $20-11$ & 0,04 & 0,08 & 0,04 & 0,09 \\
\hline $10-0$ & 0,02 & 0,06 & 0,02 & 0,07 \\
\hline
\end{tabular}

Így tehát összesen 18-18 paraméter eltárolására van szükség mind a hidrosztatikus, mind a nedves késleltetés esetében (3. táblázat). Ugyanakkor szükséges figyelembe venni, hogy ez a modell elhanyagolja a maradék hibák modell elhanyagolja a no b)

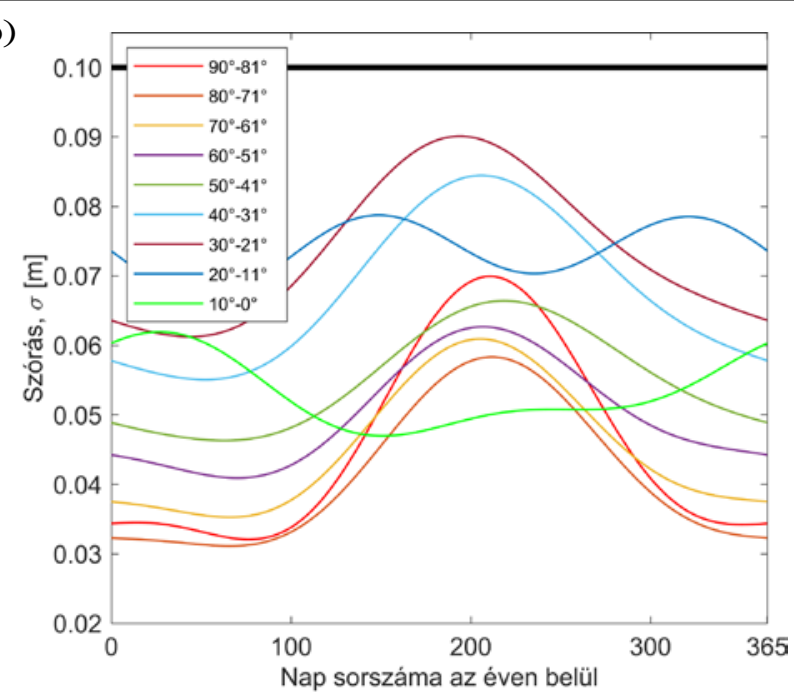

d)

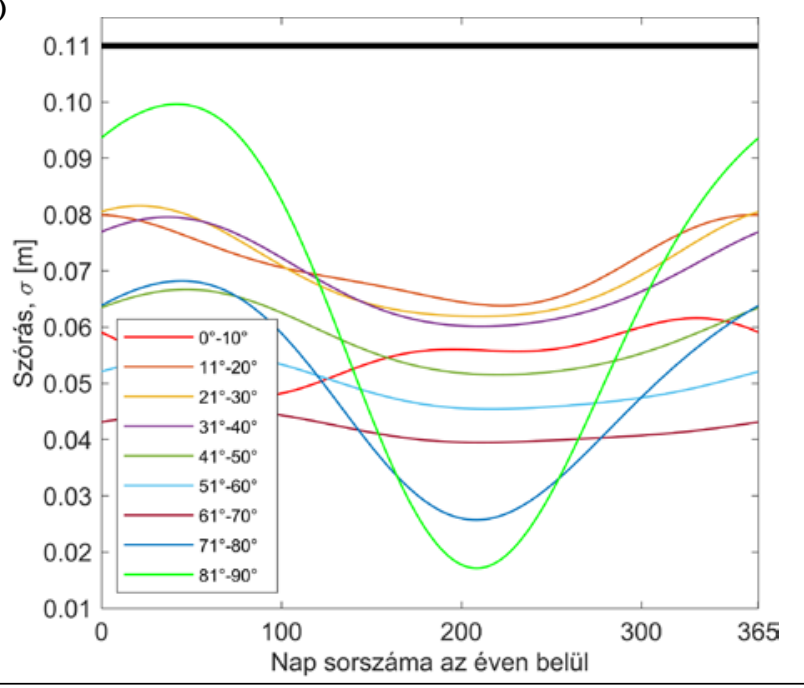

5. ábra. A maximális maradékkésleltetés-értékek szezonális váltakozása az északi féltekén

c)
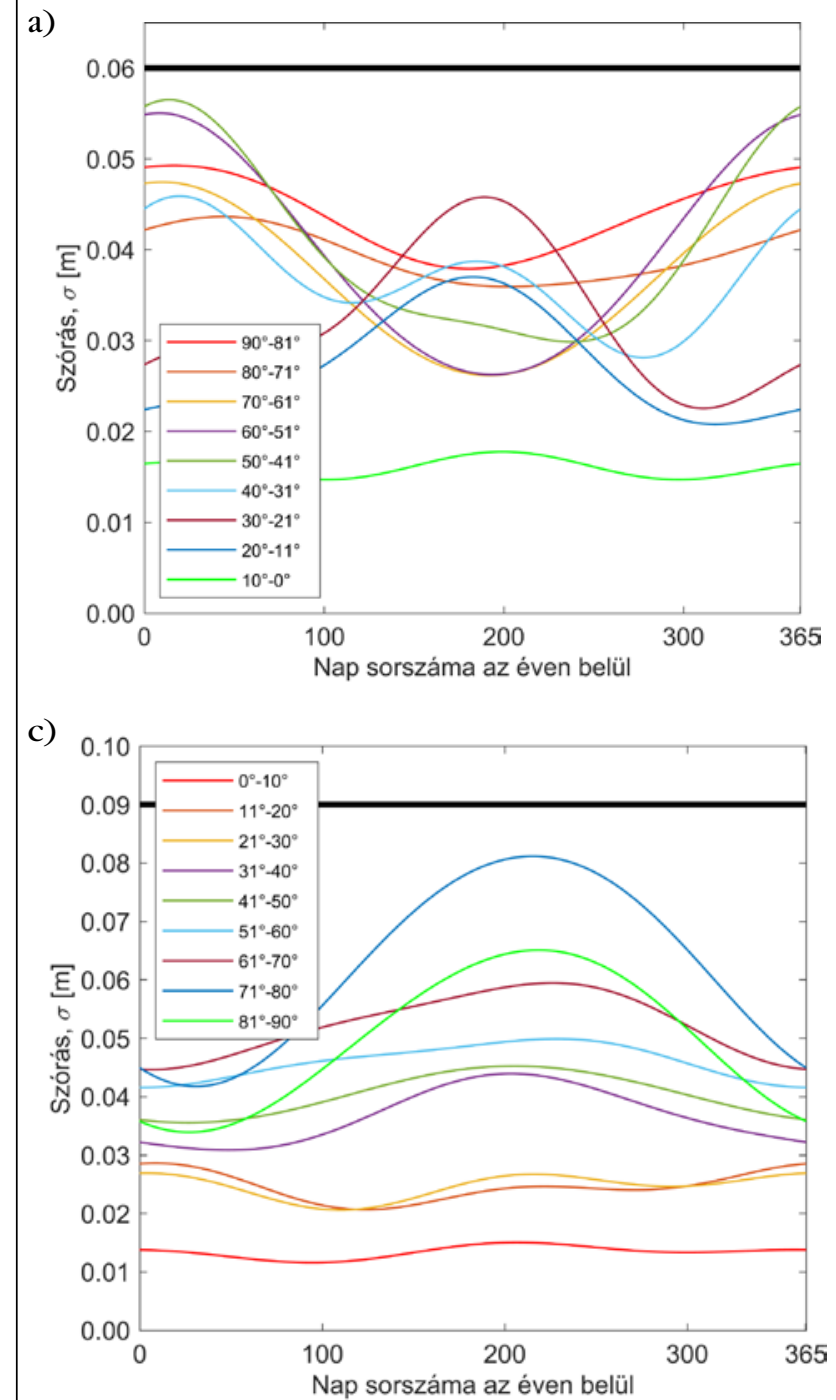
a hidrosztatikus (a) és a nedves (b), valamint a déli féltekén a hidrosztatikus (c) és nedves (d) komponensekre vonatkozóan. 


\section{Az ARTE globális konstans modell}

Az ARTE-GCM az ARTE-BCM felhasználásával került levezetésre. Mind a hidrosztatikus, mind a nedves maradék késleltetés esetében a korábban bemutatott sávos modell legnagyobb értékeit vettük figyelembe. A 3. táblázat alapján a hidrosztatikus késleltetés esetében ez 0,11 méter, a nedves késleltetés esetében pedig 0,07 méter. Az ezen az értékekból számolt, a teljes troposzferikus késleltetésre vonatkozó szigmaérték jó összhangban van az RTCA ajánlásában megfogalmazott konstans globális értékkel.

\section{Múhold irányú maradék troposzferikus késleltetés}

Az RTCA ajánlása alapján a maradék hibák kiszámítását a múhold irányában kell elvégezni. Ezért az ARTE-modellek által szolgáltatott zenit irányú késleltetések múhold irányú transzformációjára van szükség. A lépés a megfelelô leképzési függvények alkalmazásával könnyedén elvégezhetô, majd a teljes múhold irányú maradék késleltetés az alábbiak szerint számítható:

$\sigma_{\max , S T D}=\sqrt{\sigma_{\max , Z H D}^{2} \cdot m_{h}^{2}+\sigma_{\max , Z W D}^{2} \cdot m_{w}^{2}}$

ahol $m_{h}$ és $m_{w}$ a hidrosztatikus, illetve a nedves összetevôkhöz tartozó leképzési függvényegyütthatók az egyes múholdakra vonatkozóan. Továbbfejlesztve az RTCA-modellt, amely csak egyetlen leképzési függvény használatára ad lehetôséget, az ARTE-modellek becsléseinél az egyes összetevôkre akár eltérô leképzési függvények is alkalmazhatók.

\section{A modellek validációja IGS-referenciaadatok felhasználásával}

Annak érdekében, hogy a modellek felülbecslố tulajdonságát ellenốrizni tudjuk, a Nemzetközi GNSS Szolgálat (International GNSS Service - IGS) által szolgáltatott troposzferikus késleltetési értékekre épülő validációt végeztünk. Azért esett az IGS-adatok felhasználására a választásunk, mivel a GNSS mérésekből levezetett troposzferikus késleltetések függetlenek a bemenő adatként felhasznált numerikus légköri modellektől. Az egyes IGS-állomásokon mért késleltetési értékek szabadon hozzáférhetôk az IGS globális adatközpontján keresztül. Mivel egyes állomásokon jelentős hézagok találhatók az adatsorokban, így a validáció elvégzése elôtt a rendelkezésre álló 300 állomásból 49 olyan állomást választottunk ki, amelyeknél a legzavartalanabb az adatok folytonossága, valamint megfelelóen elosztva találhatók a Föld felszínén. 2000. január 1. és 2017. október 31. közötti időszakban napi egy (12:00 UTC) késleltetésértéket használtunk fel a validációra. Mivel a $81^{\circ}-90^{\circ}$ szélességi sávban sem az északi, sem a déli féltekén nem található állomás, így ezen sávokra vonatkozó modellek validációját nem tudtuk elvégezni.
A teljes, nem modellezett, ún. maradék troposzferikus késleltetésértékeket az RTCA MOPS által becsült értékek IGS-referenciaértékekből történô kivonásával határoztuk meg. Ezeket a maradék hibákat aztán összehasonlítottuk az ARTE-modellek által szolgáltatott értékek alapján kiszámított védelmi szintekkel.

A validáció eredményének szemléltetésére az ún. Stanford-ábrákat használtunk. Az ábrák az IGS-adatok segítségével kiszámolt maradék hibák és az ARTE-BSM (6. a) ábra) valamint az ARTE-BCM (6. b) ábra) által meghatározott védelmi szintek közötti kapcsolatot szemléltetik két szélességi sávra. Mint az az ábrából is látható, a ARTEBCM esetében a Stanford-ábra egyetlen sávot mutat mindössze, amelyre tulajdonképpen a megfelelô ARTE-BSMmodellból számított védelmi szintek lettek rávetítve.

\section{Validáció extrém idôjárási körülmények esetén}

A horvátországi Zadar környékén rendkívül nagy mennyiségú csapadék hullott 2017. szeptember 10-11 között. Az idôjárási megfigyelések alapján napi négy, egyenként hatórás idôszakot lefedô csapadéktérképet készítettünk el az Országos Meteorológiai Szolgálat (OMSZ) által rendelkezésre bocsátott nagy felbontású, $0,1^{\circ} \times 0,1^{\circ}$-os ALADIN-idôjárásmodell segítségével.
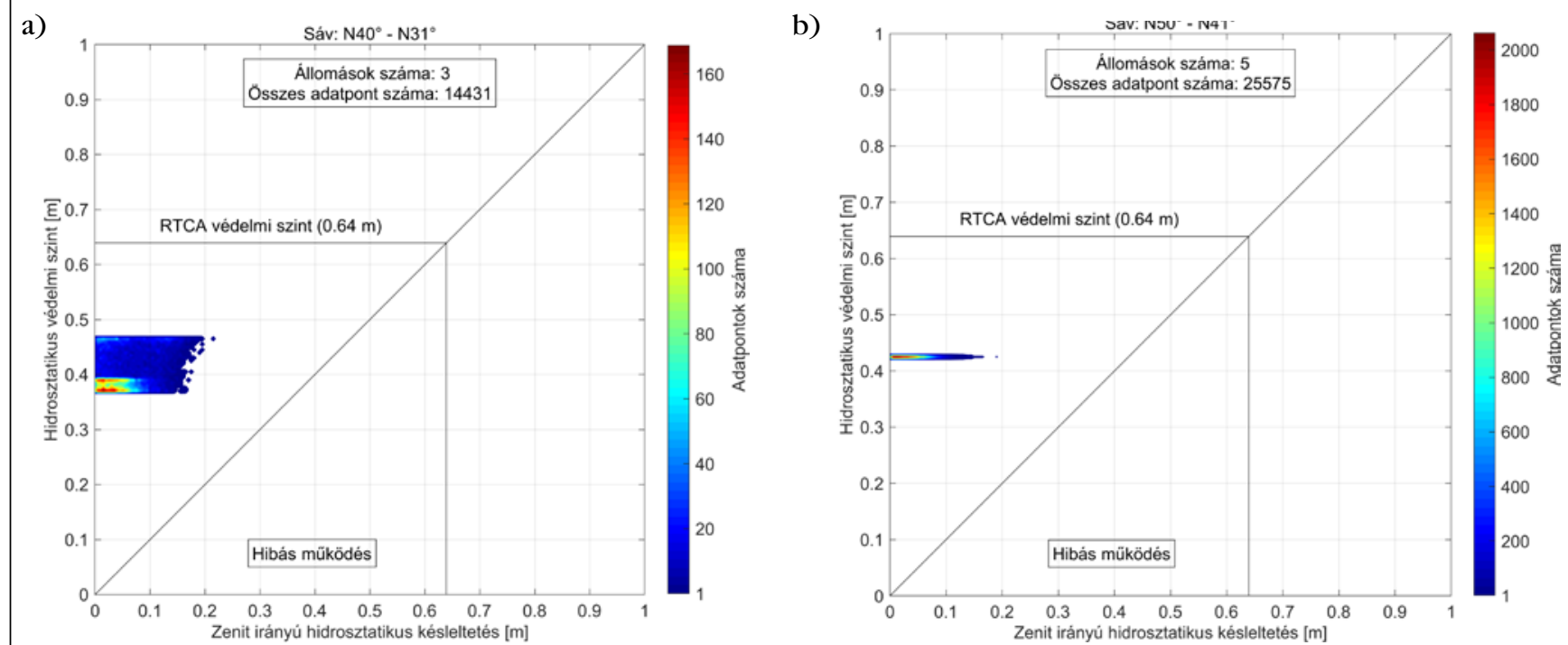

6. ábra. Az ARTE-BSM (a) és az ARTE-BCM (b) modellek validációja két eltéró szélességi sávban. Az ábrán az RTCA MOPS-modell által megadott védelmi szint is feltüntetésre került. 
A szeptember 11-én, 6-12 óra közötti csapadéktérkép szerint ebben az időszakban Zadarban $59 \mathrm{~mm}$ csapadék hullott.

A validáláshoz szükséges referenciaadatokat a korábban bemutatott sugárkövetés módszeréhez hasonló, de továbbfejlesztett algoritmussal számítottuk. A nagy felbontású modell alkalmazása miatt, ebben az esetben már figyelembe kellett vennünk a számításokban azt az esetet is, amikor a sugár elhagyja a kezdeti, állomás feletti vertikális profilt, és egy szomszédos vertikális profilba kerül át.

Az eredmények (7. ábra) megfelelnek annak az elvárásnak, hogy az RTCA MOPS troposzféra késleltetési modell egy ilyen szélsőségesen csapadékos idôszakban alulbecsüli a nedves troposzferikus késleltetést. Meg kell jegyeznünk, hogy az ARTE-BSM- és RTCA MOPS-integritásmodellek is megfelelően konzervatív becslést adnak a nem modellezett troposzferikus késleltetés hibára mind a hidrosztatikus, mind a nedves késleltetés esetére. Viszont az ARTE-BSM-modell hatékonyabbnak bizonyul a hibabecslésnél, kisebb védelmiszintérték mellett továbbra is megbízható becslést ad a maradék hibákra.

\section{Eredmények és konklúzió}

Tanulmányunkban egy új, a troposzferikus maradék ellentmondások modellezésére szolgáló eljárást mutattunk be. A modellek levezetéséhez numerikus idôjárásmodellekből származó, 17 évnyi időszakot átölelő adatsort és a sugárkövetés módszerét használtuk fel. A meghatározott modellek három különbözô komplexitási szinten kerültek kialakításra attól függôen, hogy figyelembe veszik-e a maradék hibák szezonális, illetve éghajlati függését. Amennyiben egyik hatást sem vesszük figyelembe, a létrehozott modell jó összhangot mutat a jelenleg de facto szabványként felfogható RTCA MOPS maradék troposzferikus késleltetés modelljével. Ugyanakkor azt is bemutattuk, hogy az új modellek jelentôsen hatékonyabbnak bizonyulnak, amennyiben a szezonális és az éghajlati változásokat figyelembe veszszük, és ezáltal javítják a GNSS-alapú helymeghatározás elérhetôségét és folytonosságát.

Annak érdekében, hogy a bemutatott modelleket ellenórizni tudjuk, két validációs eljárást hajtottunk végre. $\mathrm{Az}$ IGS által szolgáltatott troposzferikus késleltetések mint referenciaadatok felhasználásával egy hosszabb időszakra vizsgáltuk, hogy a modellek megfelelố mértékben felülbecsülik-e a fellépố troposzferikus maradék késleltetéseket.

A modellek extrém idôjárási körülmények közötti múködését egy esettanulmány segítségével vizsgáltuk meg, nagy felbontású numerikus idôjárásmodellből származó adatok felhasználásával. Az extrém időjárási körülmények ebben az esetben egy rövid, de igen intenzív csapadékos idôszakot takartak.

A levezetett modellek mindkét esetben hatékonyabbnak bizonyultak a maradék hibák becslésében, mint a jelenleg alkalmazott RTCA MOPS-modell. A modellek ugyanakkor továbbra is megfelelô mértékben felülbecsülik a maradék ellentmondásokat, így tehát nincs szükség kompromisszumokra még a magas integritásigényú alkalmazások esetében sem.

Figyelembe veendô továbbá, hogy a modellek levezetéséhez használt eljárás alkalmazható bármilyen más troposzferikus késleltetésmodell, mint például az ESA GALTROPO (Krueger et al. 2004) vagy a GPT2W (Boehm et al. 2014) esetére is. Utóbbi eredetileg a felszíni meteorológiai paraméterek becslésére kifejlesztett modell, mely bemeneti adatokkal szolgálhat olyan troposzferikus késleltetéseket számító modellekhez, mint például az Askne és Nordius (1987) által kifejlesztett eljárás.

\section{Köszönetnyilvánítás}

A szerzók ezúton is köszönik az Európai Ûrügynökség (European Space Agency - ESA) támogatását, amelyhez a 40000114534/15/NL/Nde számú szerzôdésen keresztül jutottak hozzá.
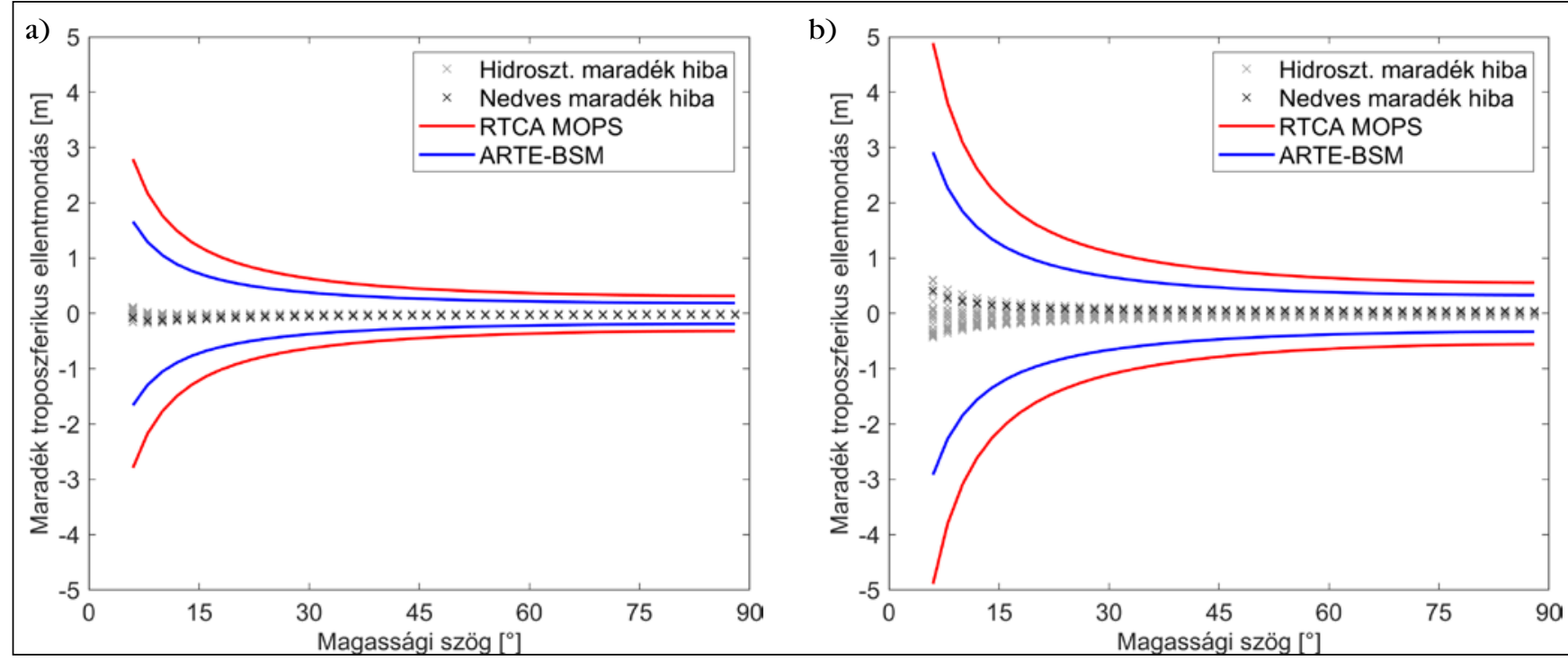

7. ábra. Maradékhiba-értékek a hidrosztatikus a) és nedves b) RTCA MOPS-troposzféramodellel számított késleltetések alapján a két vizsgált integritásmodell maximális maradék hibáival együtt 


\section{Irodalomjegyzék}

Askne, J. - Nordius, H. 1987. Estimation of tropospheric delay for microwaves from surface weather data. Radio Science. Vol. 22. No. 3. pp. 379-386.

Boehm, J. - Schuh, H. 2003. Vienna Mapping Functions. 16th Working Meeting on European VLBIfor Geodesy and Astrometry pp. 131-143.

Boehm, J. - Möller, G. - Schindelegger, M. Pain, G. - Weber, R. 2014. Development of an improved empirical model for slant delays in the troposphere (GPT2w). GPS Solutions. Vol. 19. No. 3. pp. 433-441.

Collins, J. P. - Langley, R. B. 1998. The residual tropospheric propagation delay: How bad can it get? 11th International Technical Meeting of the Institute of Navigation. Nashville, Tennessee.

Dee, D. P. - Uppala, S. M. - Simmons, A. J. - Poli, P - Kobayashi, S - Andrae, U. - Balmaseda, M. A. - Balsamo, G. - Bauer, P. - Bechtold, P. - Beljaars, A. C. M. - van der Berg, L. - Bidlot, J. - Bormann, N. - Delsol, C. - Dragani, R. - Fuentes, M. - Geer, A. J. - Haimberger, L. - Healy, S. B. - Hersbach, H. - Hólm, E. V. - Isaksen, L. - Kållberg, P. - Köhler, M. Matricardi, M. - McNally, A. P. - Monge-Sanz, B. M. - Morcrette, J. J. - Park, B. K. - Peubey, C. - de Rosnay, P. - Tavolato, C. - Thépaut, J. N. - Vitart, F. 2011. The ERA-Interim reanalysis: configuration and performance of the data assimilation system. Quarterly Journal of the Royal Meteorological Society. Vol 137. No. 656:553-597.

Douša, J. - Eliaš, M. - Václavovic, P. - Eben, K. - Krč, P. 2018. A two-stage tropospheric correction model combining data from GNSS and numerical weather model. GPS Solutions, Vol. 22. No. 3. pp. 77. DOI: $10.1007 / \mathrm{s} 10291-018-0742-\mathrm{x}$

ICAO - International Civil Aviation Organization. 2006. Aeronautical Telecommunication. Vol. 1., Radio Navigation Aids. In Annex 10 to the Convention on International Civil Aviation. p. 578

ISO - International Organization for Standardization. 1975. Standard Atmosphere. ISO 2533:1975, Int. Stand. Organ., vol. 2533.

Jenkinson, A. F. 1955. The frequency distribution of the annual maximum (or minimum) of meteorological elements. Quarterly Journal of the Royal Meteorological Society. Vol. 81. pp. 158-171.

Krueger, E. - Schueler, T. - Hein, W. G. Martellucci, A. - Blarzino, G. 2004. Galileo Tropospheric Correction Approaches Developed within GSTB-V1. Proceedings of the ENC-GNSS 2004. Rotterdam, the Neatherlands, May 16-19.

McGraw, G. A. 2012. Tropospheric error modeling for high integrity airborne GNSS navigation. Record - IEEE PLANS, Position Location and Navigation Symposium, pp. 158-166. DOI: $10.1109 /$ PLANS.2012.6236877

Rocken, C. - Sokolovskiy, S. - Johnson, J. M. - Hunt, D. 2001. Improved mapping of tropospheric delays. Journal of Atmospheric and Oceanic Technology. Vol. 18. pp. 1205-1213. DOI: 10.1175/1520-0426(2001)018<1205:IMO TD>2.0.CO;2

Rózsa, Sz. 2014. Modelling Tropospheric Delays Using the Global Surface Meteorological Parameter Model GPT2. 4, pp. 301-308. DOI: 10.3311/PPci. 7267
RTCA - Radio Technical Commission for Aeronautics. 2006. Minimum Operational Performance Standards for Global Positioning System/Satellite-Based Augmentation System Airborne Equipment RTCA DO-229.

Ober, P. B. 2003. Integrity Prediction and Monitoring of Navigation Systems. European Journal of Navigation 1.

Ober, P. B. - Imparato, D. - Verhagen, S. - Tiberius, C. - Veerman, H. - Van Kleef, A. - Wokke, F. - Bos, A. - Mieremet, A. 2014. Empirical integrity verification of GNSS and SBAS based on the extreme value theory. Navigation, Journal of the Institute of Navigation. Vol. 61. pp. 23-38. DOI: 10.1002/navi.55

van Leeuwen, S. S. - van der Marel, $H$. Toussaint, M. - Martelluci, A. 2004 Validation of SBAS MOPS troposphere model over the EGNOS service area. European Navigation Conference (GNSS2004). Rotterdam, The Netherlands.

\section{Summary}

In safety-of-life navigation applications of GNSS the major concern of the user is not the accuracy, but rather the integrity of the positioning service. To assess integrity, the protection level that bounds the positioning error even at very small probability levels must be determined. Recent studies show that - due to the emerging multi-frequency civilian signals - the tropospheric delay will become the most significant error source, especially at low elevation angles. The RTCA MOPS (Minimum Operational Performance Standard) for GNSS systems in aeronautics specifies a global constant for the maximum tropospheric residual error in the zenith direction. Recent studies suggest that this value is too conservative in many regions of the globe leading to lower availability and continuity of the positioning service. To overcome this limitation, a new residual tropospheric error model has to be formulated, that considers both the geographical and the seasonal variations of the tropospheric delay model performances. Our study focuses on the development of an advanced residual tropospheric delay error model (ARTE) using the methodology of extreme value analysis for the RTCA MOPS troposphere model. The developed ARTE model was validated with IGS zenith total delay (ZTD) estimates and numerical weather models obtained in a case study of extreme weather in Central-Europe. The results show that the proposed model maintained the conservatism of the original model, nevertheless yields a significantly lower residual error estimate in many regions of the globe.

Kulcsszavak: életbiztonságra veszélyes GNSS-alkalmazások, maradék troposzferikus késleltetés, troposzferikus ellentmondás-modell

Keywords: safety-of-life navigation applications of GNSS, tropospheric residual delay, Advanced Residual Tropospheric Error model - ARTE

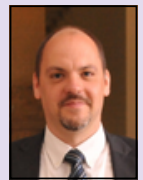

\section{Dr. Rózsa \\ Szabolcs \\ egyetemi docens}

BME Általános- és Felsőgeodézia

Tanszék

rozsa.szabolcs@epito.bme.hu

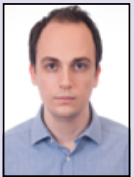

Ambrus Bence

doktorandusz

BME Általános- és Felsôgeodézia

Tanszék

ambrus.bence@epito.bme.hu

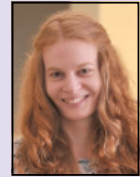

Juni Ildikó

doktorandusz

BME Általános- és Felsốgeodézia Tanszék

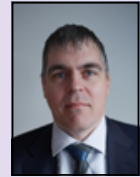

Ober Pieter

Bastiaan

ügyvezetó,

müholdas navigációs rendszerszakértó

IntegriCOM NL

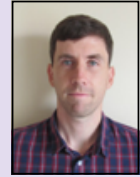

Mile Máté

meteorológus, modellfejlesztô

Országos Meteorológiai Szolgálat 